\title{
Ion mobility spectrometry reveals intermediate states in temperature-resolved DNA unfolding
}

Citation for published version (APA):

Hommersom, B., Porta, T., \& Heeren, R. M. A. (2017). Ion mobility spectrometry reveals intermediate states in temperature-resolved DNA unfolding. International Journal of Mass Spectrometry, 419, 52-55. https://doi.org/10.1016/j.ijms.2017.03.008

Document status and date:

Published: 01/08/2017

DOI:

10.1016/j.ijms.2017.03.008

Document Version:

Publisher's PDF, also known as Version of record

Document license:

Taverne

Please check the document version of this publication:

- A submitted manuscript is the version of the article upon submission and before peer-review. There can be important differences between the submitted version and the official published version of record.

People interested in the research are advised to contact the author for the final version of the publication, or visit the DOI to the publisher's website.

- The final author version and the galley proof are versions of the publication after peer review.

- The final published version features the final layout of the paper including the volume, issue and page numbers.

Link to publication

\footnotetext{
General rights rights.

- You may freely distribute the URL identifying the publication in the public portal. please follow below link for the End User Agreement:

www.umlib.nl/taverne-license

Take down policy

If you believe that this document breaches copyright please contact us at:

repository@maastrichtuniversity.nl

providing details and we will investigate your claim.
}

Copyright and moral rights for the publications made accessible in the public portal are retained by the authors and/or other copyright owners and it is a condition of accessing publications that users recognise and abide by the legal requirements associated with these

- Users may download and print one copy of any publication from the public portal for the purpose of private study or research.

- You may not further distribute the material or use it for any profit-making activity or commercial gain

If the publication is distributed under the terms of Article $25 \mathrm{fa}$ of the Dutch Copyright Act, indicated by the "Taverne" license above, 


\title{
Ion mobility spectrometry reveals intermediate states in temperature-resolved DNA unfolding
}

\author{
B. Hommersom ${ }^{\mathrm{a}, \mathrm{b}}$, T. Porta ${ }^{\mathrm{a}}$, R.M.A. Heeren ${ }^{\mathrm{a}, *}$ \\ a Maastricht MultiModal Molecular Imaging (M4I) Institute, Division of Imaging Mass Spectrometry, Maastricht University, Universiteitssingel 50, 6229 ER, \\ Maastricht, The Netherlands \\ ${ }^{\mathrm{b}}$ Biomolecular Imaging Mass Spectrometry, FOM Institute AMOLF, Science Park 104, 1098 XG, Amsterdam, The Netherlands
}

\section{A R T I C L E I N F O}

\section{Article history:}

Received 23 November 2016

Received in revised form 2 March 2017

Accepted 7 March 2017

Available online 29 March 2017

\section{Keywords:}

Ion mobility

DNA dynamics

Native mass spectrometry

\begin{abstract}
A B S T R A C T
Electrospray ionization (ESI) mass spectrometry (MS) is used to study the non-covalent interactions of short 12-mer oligonucleotides under native conditions. A home-built, temperature-controlled ESI source is employed to elevate the spray temperature above the melting temperature $\left(T_{m}\right)$ of the DNA duplexes, enabling the study of DNA interactions in the liquid phase rather than gas phase. Ion mobility spectrometry (IMS)-MS is used to investigate the 3-dimensional structure of the hybridized oligonucleotides and to track conformational changes in the oligonucleotide duplexes during temperature-induced melting in solution. Results show two additional drift times at $\mathrm{T}>35^{\circ} \mathrm{C}$, indicating 2 -fold (partial) unfolding dynamics for the DNA duplex with stable intermediates.
\end{abstract}

(c) 2017 Elsevier B.V. All rights reserved.

\section{Introduction}

Electrospray ionization (ESI) mass spectrometry (MS) is often used as a powerful tool to characterize (macro-)molecules and their complexes [1]. Over the past years, several advances have been made to provide insights in the composition, function, location, interaction and structure of the species under investigation. Particularly, native MS gives access to information about fragile species such as nucleic acids/oligonucleotides or protein complexes [2-7]. Soft ionization via ESI maintains the native conformations of those fragile species, and offers a way to study non-covalent interactions. Most of the species studied have biological relevance determined by temperature-governed dynamics. Studying those interactions and conformations require the control of the temperature or molecular energies during the ionization process as they enter the mass spectrometer [8]. This approach has been utilized by Benesch et al. in their work on a small heat shock protein with the use of a heated electrospray capillary. The validity of this method is shown in the dissociation of multimeric protein complex under influence of a temperature shift [9-11]. In another example Frahm et al. studied response factors related to the hydrophobicity of DNA samples by denaturing the DNA with the use of a heated capillary interface. Their effort is focused on the increase in response factors and

\footnotetext{
* Corresponding author.

E-mail address: r.heeren@maastrichtuniversity.nl (R.M.A. Heeren).
}

demonstrates the ability to aid in the desolvation process [12]. In this paper we studied the liquid-phase thermal behavior of short 12-mer DNA strands using ion mobility spectrometry (IMS)-MS, which also provides structural information of the analyzed species [13-18], by accurately controlling the spray solvent temperature. Ion mobility separates ions based upon their differential mobility in a buffer gas, depending on their shape, mass and charge [19]. The drift time reflects the collision cross-section (CCS) of the molecule of interest in the presence of an inert buffer gas. Here, the molecule of interest is a hybridized DNA duplex. Unfolding of the DNA duplex is reflected in an additional population with a different drift time as a CCS change occurs. Results show temperature-resolved partial unfolding of DNA duplexes under native conditions.

\section{Methods}

\subsection{Chemicals}

Ammonium acetate $(5 \mathrm{M})$ solution, methanol $(\mathrm{MeOH})$ and 2-propanol were obtained from Sigma Aldrich (Zwijndrecht, The Netherlands). Ambion Nuclease free water (deionized) was obtained from ThermoFisher Scientific (Breda, The Netherlands). Synthetic 12-mer oligonucleotide DNA strands (named B: TCTCAA-CTC-GTA - 3580.4 g/mol, and B': TAC-GAG-TTG-AGA $3709.5 \mathrm{~g} / \mathrm{mol}$ ) were purchased lyophilized and RP-cartridge purified from Eurogentec (Liege, Belgium), and used without further purification. The two 12-mer complementary DNA strands were 


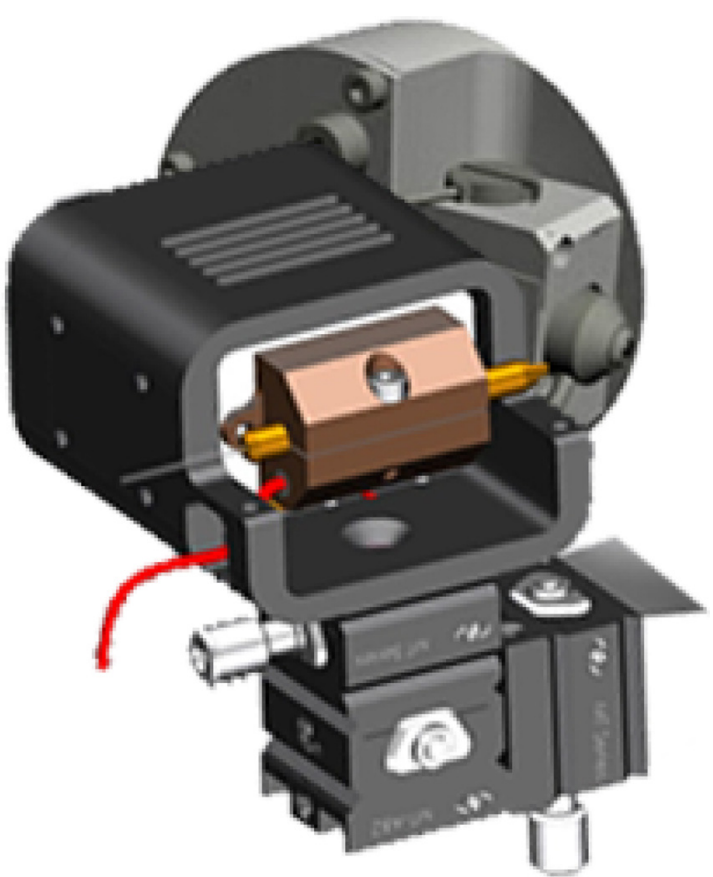

Fig. 1. Schematic representation of the temperature-controlled ionization source. Temperature control is established via a PC-controlled Peltier element (not visible because of the white ceramic plate to isolate the heating source from the high voltage supply attached by the red wire). A glass pipette is inserted between two copper clamps and put in the copper heating block. A small xyz stage allows for careful positioning of the spray tip before the API of the mass spectrometer. (For interpretation of the references to colour in this figure legend, the reader is referred to the web version of this article.)

designed to avoid hairpins and self-complementary strand formation. The oligonucleotides were stored at $-20^{\circ} \mathrm{C}$.

\subsection{Sample preparation of duplex DNA}

All DNA samples were prepared by adding $10 \mu \mathrm{M}$ of each single strand in an aqueous solution of $150 \mathrm{mM}$ ammonium acetate with $33 \%$ 2-propanol. $10 \%$ of methanol was added to the mixture solution to enhance the ESI signal. The total DNA concentration in all samples was $10 \mu \mathrm{M}$. Duplex formation was induced by the presence of ammonium acetate. The sample is stored at $7^{\circ} \mathrm{C}$ for $20 \mathrm{~min}$ to stimulate complete hybridization prior to introduction into the mass spectrometer.

\subsection{Instrumentation}

Mass spectrometry experiments were performed on a Waters Synapt G2Si High Definition mass spectrometer (HDMS) system equipped with a home-built, temperature-controlled ESI interface. The source was designed to control the temperature of the liquid before the actual formation of the spray. A partial cross section of the temperature controlled source is shown in Fig. 1. A glass spray pipette held between two copper clamps was inserted in a copper heating block. The temperature of the heating block is adjusted by a PC-controlled Peltier element separated by a ceramic plate for electric isolation. High voltage (HV) to the copper heating block is supplied by an external source. Acquisitions were performed in negative ionization mode over the mass range $m / z$ 300-4000. General operating conditions were: ESI voltage: $1.4 \mathrm{kV}$; ESI source temperature: $150^{\circ} \mathrm{C}$; sampling cone: $40 \mathrm{~V}$. Ion mobility separation was performed using nitrogen as a drift gas with a flow rate of $90 \mathrm{~mL} / \mathrm{min}$. The TRAP DC entrance was set to $0 \mathrm{~V}$ and the wave height was set to $40 \mathrm{~V}$. The velocity of the IMS wave was used to

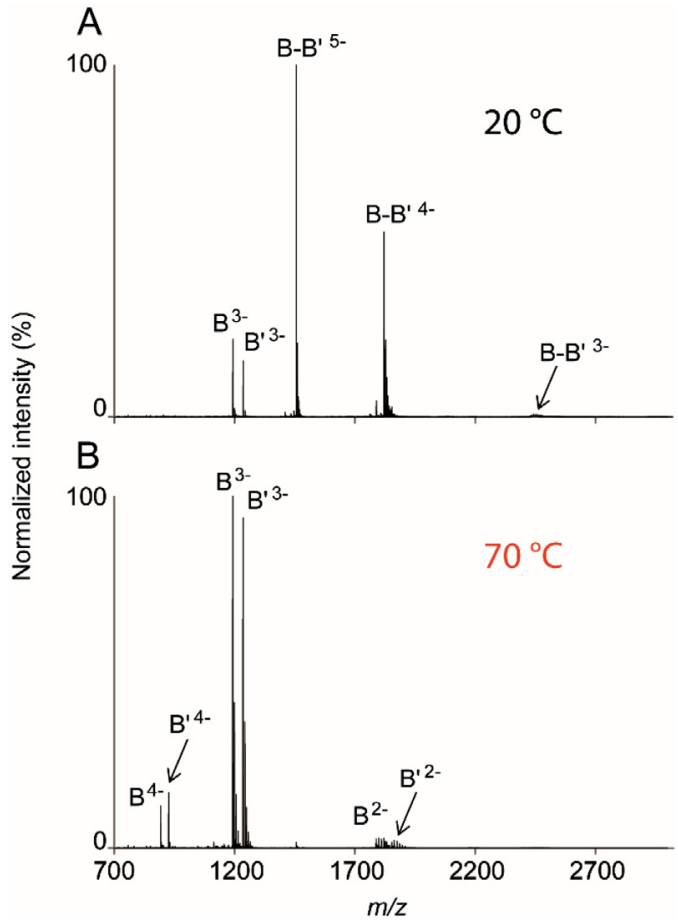

Fig. 2. Mass spectra of the DNA sample at $20^{\circ} \mathrm{C}$ (A) and $70^{\circ} \mathrm{C}(\mathrm{B})$. At $20^{\circ} \mathrm{C}$, the spectrum displays mainly the hybridized DNA at $m / z 1456$ (B-B' ${ }^{5-}$ ) and 1821 (B-B' ${ }^{4-}$ ). At $70^{\circ} \mathrm{C}$, the spectrum shows single-stranded DNA at $\mathrm{m} / \mathrm{z} 926 / 894$ $\left(\mathrm{B}^{4-} / \mathrm{B}^{\prime 4-}\right), 1235 / 1192\left(\mathrm{~B}^{3-} / \mathrm{B}^{\prime 3-}\right)$ and $1853 / 1788\left(\mathrm{~B}^{2-} / \mathrm{B}^{\prime 2-}\right)$. Spectra in $\mathrm{A}$ and $\mathrm{B}$ are an average of the mass spectra taken over $0-1 \mathrm{~min}$ and $13-14 \mathrm{~min}$ of the acquisition, respectively.

divide the ions over the total $200 \mathrm{~ms}$. The initial velocity was set at $1200 \mathrm{~m} / \mathrm{s}$ and the final velocity at $500 \mathrm{~m} / \mathrm{s}$.

\subsection{Software}

MassLynx 4.1 (Waters) was used for instrument control and data acquisition. Driftscope v2.5 (Waters) was used for visualization and processing of ion mobility data on a logarithmic intensity scale. software (TemperatureControllerUI) to regulate the temperaturecontrolled source via PC was developed in-house.

\section{Results and discussion}

Careful tuning of the ionization process allows for the intact detection of the DNA duplex. We varied the temperature of the solution between 20 and $70^{\circ} \mathrm{C}$ before ESI then detected the hybridization state of the DNA by MS. We observe DNA duplex dissociation when the spray temperature is increased (see Fig. 2). The mass spectra at $20^{\circ} \mathrm{C}$ and $70^{\circ} \mathrm{C}$ illustrate the extremes in temperature and its effect on the DNA duplex. At $20^{\circ} \mathrm{C}$ the DNA is in a hybridized state (Fig. $2 \mathrm{~A}$ ) while at $70^{\circ} \mathrm{C}$, the complex is dissociated, revealing the individual single strands (Fig. $2 \mathrm{~B}$ ). At $20^{\circ} \mathrm{C}$, doublestranded (ds) DNA is detected as a 3-, 4- and 5-fold charged duplex at $m / z 2428,1821$ and 1456, respectively (Fig. 2A). Single strands of the same DNA sample at $70^{\circ} \mathrm{C}$ are observed for three different charge states (-2, -3 and -4) for complementary strands B/B' at $m / z$ $1853 / 1788,1235 / 1192$ and 926/894, respectively (Fig. 2B). Spectra at different temperatures between 20 and $70^{\circ} \mathrm{C}$ show different ratios between dsDNA and single-stranded (ss) DNA related to an increase in temperature (data not shown).

The $T_{m}$ of the DNA is defined as the temperature at which $50 \%$ of the DNA duplex is separated into single strands. The presence of the DNA duplex at $20^{\circ} \mathrm{C}$ (Fig. $2 \mathrm{~A}$ ) results from two important exper- 

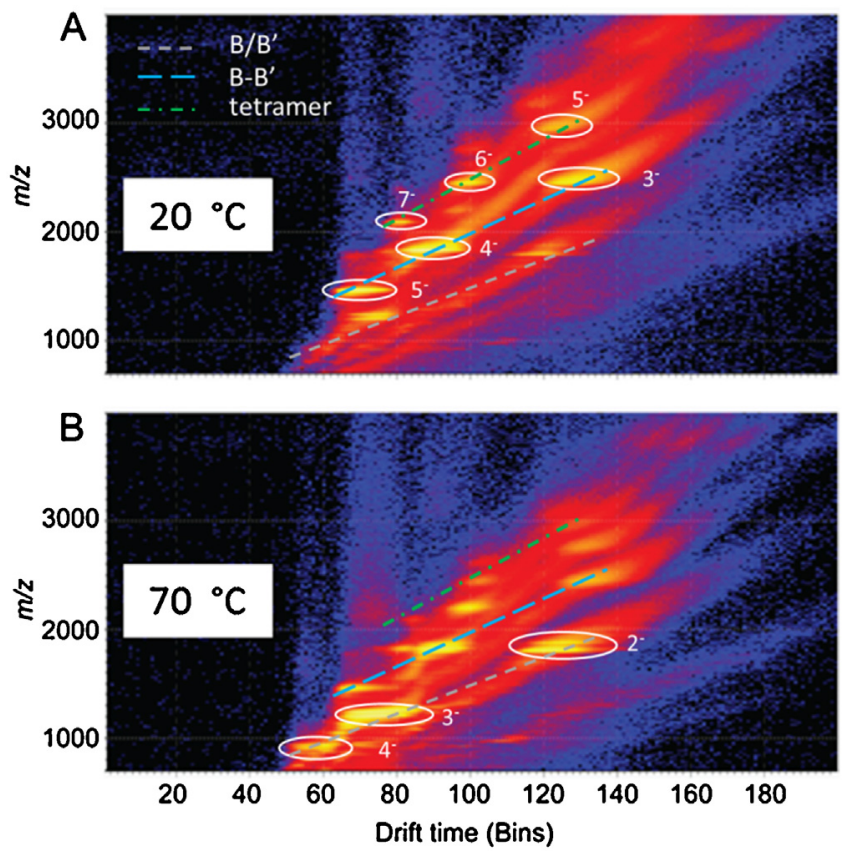

Fig. 3. Mobilogram reflecting the DNA complex dynamics in the solution phase at $20^{\circ} \mathrm{C}(\mathrm{A})$ and $70^{\circ} \mathrm{C}(\mathrm{B})$. At $20^{\circ} \mathrm{C}$, the DNA is double stranded (A) while an increase of temperature of the solution to $70^{\circ} \mathrm{C}$ resulted in the dissociation of the DNA complex (B) The trendlines of the ssDNA (B/B'), DNA duplex (B-B') and the tetramer are added in grey, blue and green, respectively.

imental aspects to consider about the formation of the DNA duplex. First, the native conditions chosen in this experiment allow for the formation of the DNA duplex. Denaturing agents (2-propanol and methanol) are present in low concentration such that annealing of the strands is possible. This is shown by the presence of the duplex at $20^{\circ} \mathrm{C}$. Secondly, the soft ionization method used in this experimental setup allows the non-covalent bonds to survive the ESI process.

DNA association and dissociation is governed by an equilibrium reaction. The ratio of DNA duplex goes from $80 \%$ to a $7 \%$ residual ssDNA under the influence of temperature going up from $20^{\circ} \mathrm{C}$ to $70^{\circ} \mathrm{C}$. This allows us to follow the dynamics of duplex behavior even though our experiments were performed above $\mathrm{T}_{\mathrm{m}}$. Because the temperature of the source was the only variable in this experiment, our results demonstrate that the shift in this process is caused by the change in spray solution temperature only.

Ion mobility yields additional information that reflects the CCS of the complex and its constituents. Unfolding of a molecular complex will result in an increase in CCS and thus an increase in the drift time of that complex. IMS-MS separates intermediate conformations based on their specific drift time. Performing IMS on the DNA sample at $20^{\circ} \mathrm{C}$ and $70^{\circ} \mathrm{C}$ we found narrow, well defined drifttime trendlines of the different species and decreasing charge states as drift time increases (Fig. 3). The drift-time trendlines originate from ssDNA, the dsDNA and an additional tetramer and show bands in the mobilogram which are caused by adducts that increase the cross-section of the fragment, thereby increasing its drift time. The ion mobility distribution as a function of molecular weight at $20^{\circ} \mathrm{C}$ shows the majority of the DNA being double stranded (Fig. 3A). A small fraction of the DNA is visible as tetramer, a duplex of DNA duplexes. At $70^{\circ} \mathrm{C}$, the mobilogram shows a dissociated state for the DNA (Fig. 3B). Clear differences were observed and the resulting melting products occupy a much broader drift-time space, indicative of unfolding of the different DNA strands.

We applied a temperature ramp from $20^{\circ} \mathrm{C}$ to $70^{\circ} \mathrm{C}$, increasing at $5^{\circ} \mathrm{C} / \mathrm{min}$, and continuously recorded the ion mobility to analyze the DNA state as a function of temperature. We focused our analysis of the dissociation of the duplex DNA on the 4-fold charged duplex $\left(\mathrm{dsDNA}^{4-}\right)$. Note that the 8 -fold charged tetramer is separated out at the different mobility trendline and does not interfere with this analysis. A main drift time peak was observed at around $9.5 \mathrm{~ms}$ for all recorded temperatures (Fig. 4). An additional drift time peak at $13.5 \mathrm{~ms}$, and from $35^{\circ} \mathrm{C}$ onward augments as temperatures increases further (Fig. 5). The peak at $13.5 \mathrm{~ms}$ reflects an intermediate conformation of the DNA duplex with a larger cross-section. An third drift time peak at $8.25 \mathrm{~ms}$, splitting off of the main peak, was observed at $\mathrm{T}>35^{\circ} \mathrm{C}$, indicating a (partial) two-step unfolding of the hybridized DNA. A similar splitting effect was observed for dsDNA $^{5-}$ (Fig. S1): a single main peak around $7.4 \mathrm{~ms}$ was observed at temperatures $20^{\circ} \mathrm{C}$ to $70^{\circ} \mathrm{C}$ and two additional peaks at 9.5 and $11.5 \mathrm{~ms}$ were observed at $\mathrm{T}>45^{\circ} \mathrm{C}$ (Fig. S2). These results reveal intermediate conformations in the DNA dissociation. This indicates a stepwise unfolding of DNA when the temperature is increased above the $T_{m}$.

Our findings are in agreement with Burmistrova et al. [20], who demonstrated an $8 \%$ compaction of an 18-mer DNA strand solely composed of GC base pairs. Our 12-mer DNA strands have $42 \%$ GC content, which could explain why the compaction effect was less pronounced in our experiments. Indeed, for the dsDNA ${ }^{5-}$, a shift in the drift time of $-3 \%$ was observed. For the dsDNA ${ }^{4-}$ a shorter drift time was observed at $9.0 \mathrm{~ms}$. Burmistrova et al. further describe the partial unfolding of DNA strands in the gas phase for which they propose partially opened structures. Our observed drift times for both the $4^{-} / 5^{-}$duplexes indicate this is also the case in the liquid phase, as determined in this experiment.

\section{Conclusion}

We have described the application of a temperature-controlled electrospray ionization source in combination with IMS-MS. This combination allowed the analysis of the hybridization behavior of short DNA strands by controlling the temperature of the source before spraying. The presented results show additional drift times for various temperatures of DNA dehybridization states, indicating that different intermediate conformers are present at elevated temperatures of the sample liquid before the ionization spray. Our findings demonstrate the temperature induced unfolding dynamics

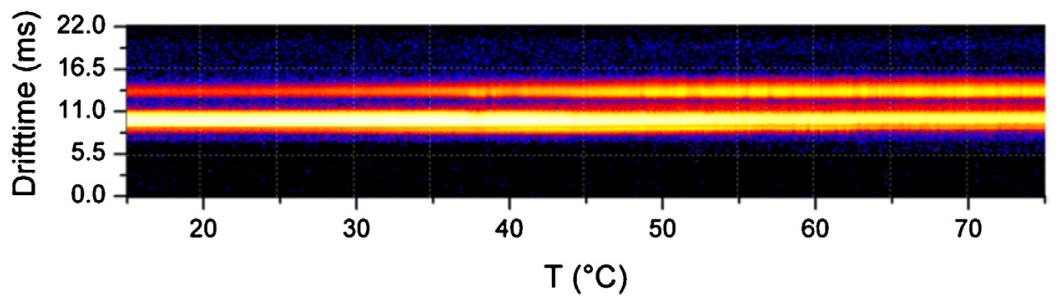

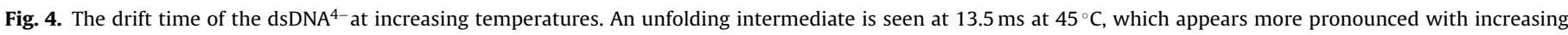
temperatures. A small shoulder-peak at $8.25 \mathrm{~ms}$ is also observed at temperatures $>35^{\circ} \mathrm{C}$. 


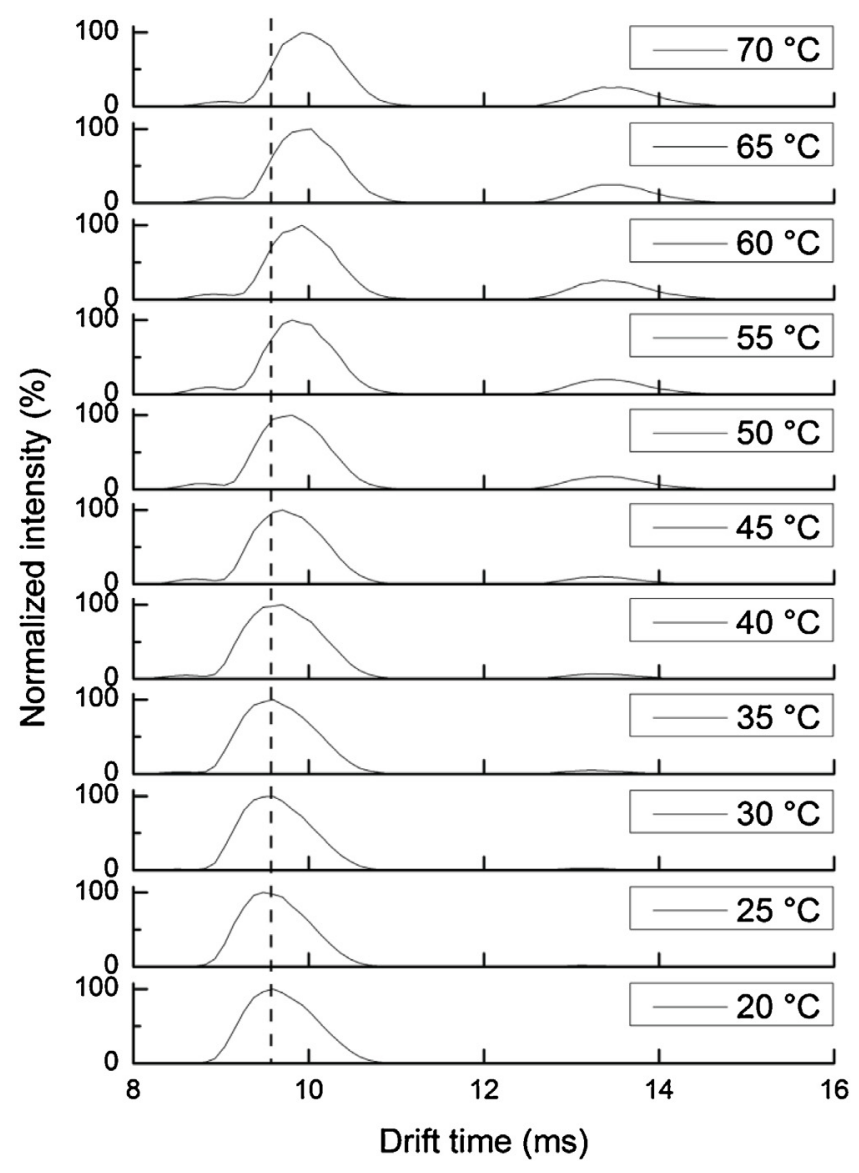

Fig. 5. The normalized intensity for the dsDNA ${ }^{4-}$ versus the drift time, stacked from $20^{\circ} \mathrm{C}$ to $70^{\circ} \mathrm{C}$. With increasing temperatures, both a drift time peak at $13.5 \mathrm{~ms}$ and a small shoulder peak around $8.25 \mathrm{~ms}$ appear. Data originates from a window of $2{ }^{\circ} \mathrm{C}$, for example $25 \pm 1{ }^{\circ} \mathrm{C}$.

for DNA duplexes in solution phase, rather than the gas phase. We foresee the use of our interface coupled to ion mobility to provide useful insights not only about the characterization of DNA behavior and DNA-DNA hybridization in the liquid phase, but also to other applications such as RNA or protein-protein interactions in conditions close to their native environment.

\section{Acknowledgments}

Part of this research is supported by the Dutch Technology Foundation (STW), which is the Applied Science Division of the Nederlandse organisatie voor Wetenschappelijk Onderzoek (NWO). This work is part of the research program of the Stichting voor Fundamenteel Onderzoek der Materie (FOM), which is finan- cially supported by the NWO. This work was in part performed in the M4I research program financially supported by the Dutch Province of Limburg as part of the "LINK" program. Dr. Tiffany Porta acknowledges support from the Swiss National Science Foundation within the "SNSF Early Postdoc Mobility-Fellowships" program (grant P2GEP2_148527). We are grateful to Marco Konijnenburg (FOM-AMOLF) for the development of the Temperature Controller software.

\section{Appendix A. Supplementary data}

Supplementary data associated with this article can be found, in the online version, at http://dx.doi.org/10.1016/j.ijms.2017.03.008.

\section{References}

[1] J. Snijder, A.J.R. Heck, Annu. Rev. Anal. Chem. (Palo Alto. Calif). 7 (2014) 43-64.

[2] F. Rosu, E. De Pauw, V. Gabelica, Biochimie 90 (2008) 1074-1087.

[3] V. Gabelica, E. De Pauw, Int. J. Mass Spectrom. 219 (2002) 151-159.

[4] F. Rosu, V. Gabelica, C. Houssier, E. De Pauw, Nucleic Acids Res. 30 (2002) e82.

[5] X. Shi, Y. Nishimura, S. Akashi, A. Takamizawa, K. Hiraoka, J. Am. Soc. Mass Spectrom. 17 (2006) 611-620.

[6] J. Gidden, E.S. Baker, A. Ferzoco, M.T. Bowers, Int. J. Mass Spectrom. 240 (2005) 183-193.

[7] A.J.R. Heck, R.H.H. van den Heuvel, Mass Spectrom. Rev. 23 (2004) 368-389.

[8] G. Wang, R.R. Abzalimov, I.A. Kaltashov, Anal. Chem. 83 (2011) 2870-2876.

[9] J.L.P. Benesch, F. Sobott, C.V. Robinson, Anal. Chem. 75 (2003) 2208-2214.

[10] R.B.J. Geels, S. Calmat, A.J.R. Heck, S.M. van der Vies, R.M.A. Heeren, Rapid Commun. Mass Spectrom. 22 (2008) 3633-3641.

[11] R. Daneshfar, J.S. Klassen, J. Am. Soc. Mass Spectrom. 15 (2004) 55-64.

[12] J.L. Frahm, D.C. Muddiman, M.J. Burke, J. Am. Soc. Mass Spectrom. 16 (2005) $772-778$.

[13] F. Lanucara, S.W. Holman, C.J. Gray, C.E. Eyers, Nat. Chem. 6 (2014) 281-294.

[14] J. Abi-Ghanem, V. Gabelica, Phys. Chem. Chem. Phys. 16 (2014) 21204-21218.

[15] E.S. Baker, M.T. Bowers, J. Am. Soc. Mass Spectrom. 18 (2007) 1188-1195.

[16] A. Politis, A.Y. Park, Z. Hall, B.T. Ruotolo, C.V. Robinson, J. Mol. Biol. 425 (2013) 4790-4801.

[17] I. Campuzano, M.F. Bush, C.V. Robinson, C. Beaumont, K. Richardson, H. Kim, H.I. Kim, Anal. Chem. 84 (2012) 1026-1033.

[18] B.T. Ruotolo, S.J. Hyung, P.M. Robinson, K. Giles, R.H. Bateman, C.V. Robinson, Angew. Chemie - Int. Ed. 46 (2007) 8001-8004.

[19] C.S. Creaser, J.R. Griffiths, C.J. Bramwell, S. Noreen, C.A. Hill, C.L.P. Thomas, Analyst 129 (2004) 984.

[20] A. Burmistrova, V. Gabelica, A.S. Duwez, E. De Pauw, J. Am. Soc. Mass Spectrom. 24 (2013) 1777-1786 